\title{
Presenças e mobilidades transfronteiriças entre Brasil, Peru e Colômbia: o caso da "migração peruana na amazônia brasileira"
}

José Miguel Nieto Olivar ${ }^{1}$

Flávia Melo da Cunha

Patrícia Carvalho Rosa

\section{Resumo}

A partir do compartilhamento das nossas experiências de pesquisa e de ensino na tríplice fronteira Brasil-Peru-Colômbia, este artigo avança na construção de um problema de pesquisa para a compreensão de intensas e diversas mobilidades em e através do território transfronteiriço. Particularmente, nos aproximamos de um dos maiores enredos e tensões contemporâneos dessa tríplice fronteira em termos de deslocamentos e da produção de desigualdades: as mobilidades e presenças peruanas aos olhos e nas terras brasileiras. Considerando que a abordagem desde "migrações internacionais" pode resultar insuficiente, propomos uma abordagem centrada na fronteira como experiência social e processo empírico, e nas mobilidades e presenças transfronteiriças levando em consideração interseccionalidades na produção de diferenças e desigualdades.

Palavras chave: tríplice fronteira; Estado; nação; desigualdades; alteridades

\footnotetext{
${ }^{1}$ Núcleo de Estudos de Gênero PAGU/ Unicamp. E-mail: escreve.ze@gmail.com

${ }^{2}$ Universidade Federal do Amazonas, Observatório da Violência de Gênero no Amazonas. E-mail: flaviamcunha@yahoo.com.br

${ }^{3}$ Antropóloga, doutoranda em Antropologia Social UNICAMP. E-mail: pati_cr@hotmail.com
} 


\section{Presence and cross-border mobility between Brazil, Peru and Colombia: the case of "peruvian migration in the brazilian amazon"}

\section{Abstract}

From the sharing of our research and teaching experiences in the triple border Brazil-Peru-Colombia, this article go forward in the construction of a research problem in understanding the intense and diverse mobility in and through the transborder territory. In particular, we approach one of the largest plot and contemporary tensions in this triple border in terms of mobilities and production of inequalities: the mobility and Peruvian presence seen from the point of view of Brazilians and in Brazilian lands. Whereas the approach from "international migration" could result insufficient, we propose an approach centered on the border as a social experience and empirical process, and the mobility and transborder presence considering intersectionalities in the production of differences and inequalities.

Keywords: triple border; State; nation; inequalities; alterities

\section{Introdução}

A partir do compartilhamento das nossas experiências de pesquisa e de ensino na tríplice fronteira Brasil-Peru-Colômbia, particularmente com base nas cidades de Tabatinga e Benjamin Constant (AM, Brasil), mas também em Atalaia do Norte (AM, Brasil) e Leticia (AM, Colômbia), este artigo avança na construção de um problema de pesquisa para a compreensão de intensas e diversas mobilidades em e através do território transfronteiriço. Particularmente, nos aproximamos do que consideramos ser um dos maiores enredos e tensões contemporâneos dessa 
tríplice fronteira em termos de deslocamentos e da produção de desigualdades: as mobilidades e presenças peruanas aos olhos e nas terras brasileiras. "O Peru" e "os peruanos" constituem para muitas pessoas brasileiras e também colombianas, nessa tríplice fronteira, uma presença que precisa ser constantemente identificada, localizada e desqualificada como invasora, malandra, nojenta, perigosa, pouco confiável ou como vulnerável. Essa percepção, muito generalizada e consistente, permeia tanto âmbitos acadêmicos como de políticas públicas e nela ideias sobre nação e migração parecem centrais.

Este artigo surge do que poderíamos chamar de uma experiência multiposicionada em campo. Isto é, o site objeto desse processo coletivo de pesquisa pode ser imaginado como um só, ainda que intensamente diversificado e múltiplo no seu interior: a porção/ perspectiva brasileira nessa tríplice fronteira. Mas a sua abordagem vem sendo realizada desde múltiplos corpos e posições entrelaçadas. Patrícia Carvalho Rosa é doutoranda em antropologia social na Universidade Estadual de Campinas e desenvolve sua pesquisa, iniciada em 2012, focalizando noções de casar e casamentos entre grupos de interlocução Ticuna no Brasil, estendendo os circuitos de diálogos entre as cidades de Benjamin Constant, Tabatinga e algumas aldeias Ticuna em território brasileiro. Flavia Melo da Cunha é professora no Instituto de Natureza e Cultura da Universidade Federal de Amazonas em Benjamin Constant há cinco anos, trabalha em temas de violência, segurança pública, gênero e direitos humanos e é a criadora e coordenadora do Programa Observatório de Violência de Gênero no Amazonas, que articula atividades de ensino, pesquisa e extensão e do qual os três autores fazemos parte. Finalmente, José Miguel Nieto Olivar desenvolve pesquisa pós-doutoral desde 2010 junto ao Núcleo de Estudos de Gênero PAGU/Unicamp sobre gênero, Estado e economias sexuais nessa tríplice fronteira tendo como base do seu campo etnográfico a cidade transfronteiriça de Tabatinga/Leticia/Santa Rosa entre 2011 e 2013. 
Nossos trabalhos de pesquisa não estiveram até agora diretamente focados no Peru, mas esse enredo social e relacional que será apresentado a partir de dados etnográficos na primeira parte deste artigo, penetrou por diversos caminhos e formas os nossos trabalhos e a nossa vida em Tabatinga, em Benjamin Constant, em Atalaia do Norte e nas aldeias indígenas do complexo da Terra Indígena Santo Antônio. É nesse encontro de múltiplas posições que a produção vigiada e desigual do "Peru" por parte de brasileiros - e colombianos - surge como um instigante problema de pesquisa e nos provoca questionamentos maiores sobre os deslocamentos e as presenças transfronteiriças e, ainda mais, sobre o que estes enredos relacionais comunicam a respeito da produção da nação, do Estado, da fronteira.

Nesse panorama de impressões e evidências empíricas, nos surpreendeu a falta de dados institucionais e de reflexões acadêmicas mais apuradas que dessem conta das questões observadas. $\mathrm{O}$ alcance deste artigo não é o da apresentação de resultados de investigação e de uma interpretação definitiva; buscamos, quiçá, entrar no jogo dos enredos mencionados desde um outro lugar teórico, mas também desde outro lugar empírico marcado pela etnografia e a participação ativa na vida social, política e acadêmica da fronteira. Para tanto, na primeira parte do artigo apresentamos cenas etnográficas contextualizando o cenário nos quais se configuram os enredos e tensões sobre a presença peruana. Na segunda parte do artigo apresentamos uma revisão da literatura especializada produzida no Brasil que refere à "migração peruana na Amazônia brasileira". Essa leitura cruzada nos permite formular o nosso argumento central. Consideramos que as dinâmicas de deslocamentos territoriais na tríplice fronteira Brasil-Peru-Colômbia resultam apenas parcial e insuficientemente compreendidas a partir de uma leitura de migrações inter ou transnacionais; inclusive consideramos que uma leitura dessa ordem, próxima do que Nina Glick Schiller e Noel Salazar (2012) têm chamado "nacionalismo metodológico" pode favorecer processos sociais e políticos de essencialização, de reprodução de desigualdades por diversos caminhos, de ansiedade 
reguladora e de fechamento de (certas) fronteiras. Esse argumento nos leva a buscar, na terceira sessão, uma abordagem alternativa que descentre a nação e a migração como recursos analíticos e coloque no centro a fronteira como experiência social e processo empírico (GRIMSON, 2003; ZÁRATE, 2008), as "mobilidades" (SCHILLER \& SALAZAR, 2012), o "movimento" (GUEDES, 2013) e as presenças transnacionais (SCHILLER, 2010) e transfronteiriças (STEPHEN, 2007; ALBUQUERQUE, 2010), e que considere interseccionalidades na produção de diferenças e desigualdades (BRAH, 2006; PISCITELLI, 2008a). Por fim, o caminho percorrido nos sugere entender esse enredo de mobilidades e presenças em termos de um consistente sistema social de produção de diferenças e de desigualdades que tem seu pivô numa lógica identificatória e contrastiva de nação/região/etnia.

\section{O Peru e os peruanos como dispositivo contrastivo: a nação na fronteira.}

O propósito desta sessão é apresentar a partir de dados etnográficos selecionados das nossas pesquisas e nossa vida na tríplice fronteira um consistente sistema de produção de diferenças e de desigualdades. Esse tem seu pivô em ideias de procedência/ pertencimento nacional, regional e étnico, e que coloca os peruanos, principalmente amazônicos, também conhecidos como "loretanos" 4, na posição social mais baixa, ora como sujeitos de permanente suspeita e desprezo, ora como vítimas da pobreza e dos marcos regulatórios, e a partir do qual "o Brasil" e "os brasileiros" (bem como "os colombianos") no exercício de localização e enunciação não apenas produzem a alteridade, mas se situam a si mesmos no local e se produzem enquanto hegemônicos.

Usamos como ponto de partida uma oficina sobre "A fronteira" que ministramos em setembro de 2013 na Universidade Estadu-

${ }^{4}$ Loretanos: naturais da província de Loreto, localizada na Amazônia Peruana. 
al de Amazonas em Tabatinga (UEA), a partir das principais considerações do trabalho de Ana Maria de Mello Campos (2012) sobre a atenção em saúde a gestantes peruanas oferecida no sistema público de saúde em Benjamin Constant. Na oficina participaram aproximadamente trinta homens e mulheres estudantes universitários entre 30 e 40 anos de idade, brasileiros, alguns da cidade ou das adjacências, e outros vindos de Manaus e outras regiões do país, com marcadas trajetórias de migração nas suas histórias pessoais e familiares. Essas pessoas eram funcionárias da prefeitura de Tabatinga, militares, comerciantes, professores de escola, esposas de militares (assim autodefinidas), donas de casa e um homem autoidentificado como índio.

Sintetizando as percepções manifestadas durante a oficina, podemos afirmar que sobre "a fronteira" a posição mais uniforme foi a de criticar a "fronteira aberta" e a "desigualdade" nas relações transfronteiriças, desde a expressão por parte dos participantes de um crescente sentimento nacionalista. Essa "abertura" e "desigualdade" era exemplificada com a imagem de como os colombianos e, principalmente, os peruanos poderiam entrar no Brasil e usufruir dos serviços e "da riqueza" do país, ter propriedades e montar negócios, enquanto os brasileiros não podem fazer isso "lá fora" na Colômbia pela rigidez dos controles que este país exerce em Leticia. Significativamente, ninguém manifestou desejo de fazer isso no Peru. De igual maneira, se referiram aos serviços de saúde. Criticando a posição da pesquisa de Campos (2012), disseram que como no Brasil a saúde é gratuita, todo mundo quer acessar, "mas vai tu ver se na Colômbia te atendem... Nada, lá a gente tem que pagar tudo! E cobram duro da gente!"5. 0 mesmo argumento de valores abusivos na

${ }^{5}$ Compreender essa afirmação implica saber que os sistemas de saúde do Brasil, Peru e Colômbia são extremamente diferentes. No caso colombiano a saúde pública está terceirizada através de empresas que administram recursos próprios e do estado, dependendo do caso, e às quais a população economicamente ativa deve-se afiliar pagando uma cota mensal. Isso gera um mercado paralelo de serviços de saúde privados virtualmente melhores e mais baratos como a reconhecida Clínica Leticia muito frequentada por brasileiros. 
cobrança foi operado para se referir ao valor dos bens de consumo vendidos nas lojas de produtos "importados" de Leticia e cujo público-alvo são funcionários públicos brasileiros e suas famílias, principalmente militares.

A "desigualdade" foi expressada também em termos de policiamento e regulação: segundo esta perspectiva, os colombianos e peruanos podem fazer o que querem em Tabatinga, sem controle nenhum, enquanto em Leticia o controle policial é maior. Com relação particularmente aos peruanos, foi mencionada a queixa sobre a "ocupação" ou "invasão" da região da feira, do mercado e do porto em Tabatinga. Deficitário em "presença do Estado" e em controles migratórios e tributários, segundo os participantes, "O Brasil" nessas cidades permitiria que os peruanos ocupem um espaço físico, laboral e econômico que seria brasileiro, impedindo aos brasileiros garantir maior acesso a trabalho e a dinheiro. Essas queixas são recorrentes em espaços sociais e institucionais brasileiros em Tabatinga, Atalaia do Norte e Benjamin Constant transpassando incluso ao universo acadêmico, como se faz evidente no trabalho de Oliveira (2010), que será referido na seguinte sessão do artigo ${ }^{6}$.

\footnotetext{
${ }^{6}$ Em 2011 realizamos em Atalaia do Norte o II Seminário sobre Direitos Humanos no Alto Solimões. Após uma sucessão de oficinas coordenadas por estudantes do curso de Antropologia da UFAM, o seminário reuniu diferentes segmentos sociais e participantes do projeto. Durante o debate, uma intervenção emblemática para o problema de pesquisa aqui proposto foi manifesta pela mãe de uma universitária peruana sobre as discriminações sofridas pela filha em sala de aula. Queixava-se ela que sua filha era recusada pelos colegas na composição de equipes e que se sentia envergonhada para falar em sala de aula. A reação de muitos participantes, em burburinho, foi imediata; inclusive entre alguns dos universitários que coordenavam as oficinas sobre direitos humanos. Intrigou-nos sobretudo a fala de um deles: "nós não discriminamos ninguém, todo mundo pode fazer parte dos nossos grupos, só não estudamos com preguiçosos, com quem não quer estudar".
} 
Percepções similares foram evocadas em contextos indígenas. De acordo com Patrícia Rosa, seus interlocutores Ticuna ${ }^{7}$ informavam, de modo recorrente, que "os peruanos chegam nas Terras dos indígenas para se aproveitarem de nossos recursos, da madeira, dos peixes. 0 governo (leia, especialmente, FUNAI, IBAMA, PF) não faz nada a respeito". Por outro lado, mas sem distanciar-se da desvalorização dos produtos de origem peruana, bem como das formas de conduta nos "negócios", outros Ticuna apontam algumas vantagens comerciais "no Peru", especificamente, no que diz respeito ao consumo de gasolina, porque, como dizem "lá é mais barato porque vem de Iquitos, aqui [no Brasil, em Tabatinga] é mais caro. Só que a gasolina dos peruanos é ruim, é como se fosse falsificada. Os produtos deles são assim, tipo R $\$ 1,99 "$.

Essa última percepção do interlocutor Ticuna brasileiro nos chama a atenção sobre a produção da diferença enquanto desigualdade, pois além dos peruanos usufruírem da fronteira aberta de maneira "desigual" ou "malandra", a qualidade dos seus produtos, do seu fazer, da sua participação nas relações "é ruim". Essa relação de forte discriminação baseada em identificações nacionais se produz e se expressa, também, em marcadores corporais e morais que se deslizam em marcadores étnicos que surgem em situações diversas e inesperadas sob as formas de piadas e comentários irônicos, cujo exemplos estão fartamente registrados em nossos diários de campo. Nesse sentido, são bastante ilustrativos os comentários de um jovem benjaminense que aprendeu no exército a chamar de "cebolas" aos peruanos pelo seu

\footnotetext{
${ }^{7}$ Os Ticuna conformam uma população de mais de 60.000 pessoas, distribuídos entre os países da tríplice fronteira, Colômbia (8.000: dados de 2011), Peru (6.982: dados de 2007) e Brasil (46.045: dados de 2010) (Cardozo da Silva, 2012). Como registram alguns dos importantes aportes bibliográficos voltados aos estudos da conformação da região (Goulard, 2005; Cardoso de Oliveira, [1972]1996; Oliveira Filho, 1988; GarcésLópez, 2000, 2011), esta consolidou-se historicamente há pelo menos dois mil anos, sobre o território tradicionalmente ocupado pelos Ticuna, o qual se encontra atualmente disposto entre Brasil, Peru e Colômbia, e sob diferentes projetos e legislações administrativas.
} 
cheiro, ou de uma tabatinguense, filha de peruanos, funcionária da prefeitura, que detestava seu "nariz de peruana" e a "a língua deles", pois as consideravam horríveis. Esse tipo de comentário, encontra paralelo na explicação de um professor Ticuna sobre o motivo de oferecer classes de "ticuna brasileiro" aos alunos cujos pais eram provenientes do Peru: eles [ticuna peruanos] precisam "se civilizar na língua e aprender a falar bonito como a gente".

É nesse sentido que se explica que as e os peruanos/as, principalmente aqueles/as de aspectos mais "amazônicos", "indígenas" e "pobres" ocupem um lugar mais baixo nos mercados sexuais e afetivos transfronteiriços. Sobre os homens, retóricas sobre feiura e maus cheiros se misturam com o baixo valor do Sol (moeda peruana), com as posições laborais inferiores que homens peruanos ocupam, com a sonoridade do seu sotaque e com acusações de performances comparativamente mais "machistas" deles. Enquanto às mulheres peruanas, as retóricas masculinas são ambíguas, mas tendem a uma certa exotização erotizada, porém inferiorizada (MOTTA, 2010). Não foram poucas as vezes que ouvimos de homens não-indígenas comentários sobre a quentura das peruanas, principalmente "loretanas", e, em alguns casos, sobre sua beleza "índia”, claramente sexualizada. Inclusive um jovem ticuna comentava com Patrícia em uma incursão por Tabatinga que "quero provar das brasileiras ou das colombianas, pode ser até mais caro, né? Dizem que elas são mais bonitas, ajeitadas, menos selvagens. Penso que as mulheres da vida [peruanas] que trabalham aqui [Tabatinga] são tudo meio índia”. Contrário ao que é sugerido por Torres e Oliveira (2012) sobre a participação de mulheres "amazônidas" nos mercados do sexo nacionais e transnacionais, a sexualização da condição étnica não implica nessa tríplice fronteira maior demanda, pelo contrário, as coloca em posições economicamente inferiores em um mercado do sexo que sobrevaloriza as peles claras.

A região de transações sexuais de menor valor monetário em Tabatinga é a região da Feira, tida como como um espaço urbano 
onde se articula peruanidade, ilegalidade, pobreza e indianidade. Os prostíbulos mais baratos de Tabatinga estão localizados nessa feira, são descritos e produzidos como peruanos (administradores desta nacionalidade, músicas, mulheres, frequentadores) e como relativamente mais perigosos, o que significa que, performática e discursivamente, as mulheres que ali trabalham ocupam a posição de peruanas. 0 valor base do programa em 2012 , que girava entorno de $\mathrm{R} \$ 20,00$, era menos que a metade do valor base cobrado por mulheres brasileiras, colombianas e peruanas (que fugiam desse marcador) nos reconhecidos prostíbulos brasileiro e colombiano em Tabatinga cujo valor, nesses casos, era aproximadamente $\mathrm{R} \$ 50,00$. Essa diferença está fundamentalmente atrelada à imagem de peruanidade que engloba considerações sobre beleza e idade (OLIVAR, 2013).

Aprofundando no contexto indígena, particularmente Ticuna, como tem aparecido na pesquisa de Patrícia Rosa, vemos como a lógica até aqui descrita de produção de desigualdade e de hierarquia por nacionalidade se entrelaça e atualiza em lógicas nativas, o que em outros termos implica pensar que a fronteira nacional não desaparece, mas adquire uma forma particular. A percepção sobre "os peruanos" se traduz no problema político Ticuna de casar com peruanos não indígenas, questão que situa o signo da "nacionalidade" como um operador sociopolítico que localmente os posiciona enquanto cônjuges não preferenciais, porque são descritos e classificados como "gente de fora"8 ${ }^{\text {. Nes- }}$

\footnotetext{
${ }^{8}$ Este termo de tratamento também circunscreve outras nacionalidades como a colombina e aquelas "gringas", especificando turistas europeus e norte-americanos que eventualmente chegam às aldeias de Tabatinga e Benjamin Constant e os missionários batistas estadunidenses que mantêm com os Ticuna longa trajetória de diálogos e intervenções (MACEDO, 1996). Entre os interlocutores da pesquisadora tal termo relacional aplica-se pejorativamente em relação aos homens peruanos não indígenas, diferentemente de quando são usadas para referir-se àqueles brasileiros chegados de outras regiões do país, notadamente "gentes do sul", referindo-se majoritariamente aos "militares", "professores" e "pesquisadores" com os quais também têm vínculos. Gente de fora, por fim, engloba aqueles Ticuna "parentes de longe", inclusive peruanos, que não sejam conterrâneos de aldeia/comunidade do enunciador.
} 
sa condição, esses homens peruanos não indígenas, entendidos enquanto "inimigos perigosos", evocam imagens de um longo processo de inimizades que dizem respeito à história da colonização, dos processos de fronteirização e da mitologia Ticuna.

\section{Uma mulher Ticuna brasileira casada com um desses "homens de fora" explica:}

Quando fui eu que escolhi um homem desses, papai aconselhava, dona, para largar dela, dizia que essa gente é perigosa, ele dizia que "essa gente do outro lado do rio é gente de desconfiança". (...) Sabe por quê? Porque, o velho contava assim: "lá daquele lado estão aqueles que dizemos ser awane, [inimigos]”. Assim, dona, gente que não se confia, dizia papai. Lá, dizia o velho "estão também os outros indígenas, com quem se fazia guerra, no tempo que chegou primeiro os brancos aqui, nesse tempo de brigar para ver de quem ia ser essas terras dos Ticuna. Foi esses movimentos que fizeram essas palavras nova para vida do povo Ticuna, assim fronteira, documento, nacionalidade. Assim foi".

Isso ai vem nas histórias dos antigos, do tempo dos nossos ancestrais, isso de quando Yoi virou o mundo, para fugir do seu irmão preguiço, que fazia besteira das grandes, o Ipi [referência à figuras mitológicas criadores do povo ticuna]. Aí, dona, daquele outro lado do rio ficou a morada da gente que não é parentes, os peruanos de verdade, aí tem que tomar cuidado, é gente de desconfiança esse povo ai, foi criado por esse Ipi. (...) Essa gente é como Ipi, só que no tempo de hoje: gostam de fartura e ouro; não dividem, é gente que faz bagunça, que rouba e chega aqui, em nossos lugares para roubar madeira, nossas aldeias, trazer as drogas, os pecados, pegar mulheres da gente. Diz por ai, na história do povo ticuna, dona, que esses homem peruanos fugiam de patrões, maltratavam índios; tinha desses ai que trabalhavam no tempo da seringa, da sorva, para esses patrões ai. Esses homens ai pegavam mulher da gente. Deixava barriguda, sumia depois (...) isso de pensar eles como gente perigosa e ameaça, é assim desde o tempo deles, dos criadores dos ticuna, do Yoi, e de Ipi. Depois, só vai seguindo igual, 
até hoje. É por isso, dona, que hoje a gente diz que casar bem é casar com gente desse lado do rio, casa melhor assim, se não faz como foi com meu homem: tempo de prova, de trabalho pros ticuna ver se ele é bom partido, se vira ticunado, para ficar aqui e virar bom parente, que não faz ameaça".

Vemos então como na produção desse sistema contrastivo de diferenças e desigualdades, além da nação se articular com etnia e gênero, também o faz com a procedência regional. Nesse sentido, construções hierárquicas intranacionais se atualizam e articulam em termos morais, estéticos, políticos, como já vimos no caso da exotização sexualizada das mulheres "loretanas" e como é apresentado por Motta (2010) em sua pesquisa sobre trajetórias afetivo-sexuais urbanas de mulheres na Amazônia peruana. Essa visão é atualizada nos sistemas migratórios e de mobilidades peruanas na tríplice fronteira. Para Claudia, uma empresaria peruana vinda de uma cidade próxima a Lima na "sierra", os brasileiros e colombianos têm parcialmente razão em desconfiar de peruanos, pois, segundo ela, conhecem "lo que de peor tiene el Peru". Fazendo referência principalmente à participação peruana no tráfico de drogas na região, Claudia explica que "mucha de la gente que migró para estas regiones son bandidos, expresidiarios, ex-guerrilleros del Sendero [Luminoso]". Ela, como outros peruanos não-amazônicos interessados em marcar diferença com os nativos, sejam estes indígenas ou não, também expressam esse relativo desprezo em termos ora de "pereza", de falta de vontade ou de capacidade para o trabalho ${ }^{9}$, ora em termos de selvageria e falta de civilização.

Essas construções de identidade, como também demostra Motta (2010) e como Togni (2014) analisa para o caso de jovens brasileiros em Lisboa, são relativamente incorporadas, manipuladas

\footnotetext{
${ }^{9}$ A perspectiva de desprezo ao nativo amazônico, principalmente indígena, aliás, não é exclusivamente peruana, e se replica facilmente entre brasileiros e colombianos não-indígenas e não-amazônicos que migraram por razões familiares, comerciais ou laborais; como em um consenso de colonizadores.
} 
e usadas de maneiras táticas por pessoas peruanas loretanas como Flor, uma jovem empregada de Claudia. Enquanto usa e usufrui da sua beleza "índia" e da imagem de "charapa ardiente" (Motta, 2010), ela investe pesadamente em assistir televisão brasileira, ouvir e dançar mais forró (e menos cumbia), namorar brasileiros não locais (ou colombianos brancos e profissionais) e adotar o português como sua língua cotidiana, tentando apagar interferências gramaticais ou fonéticas do espanhol "loretano" que sempre voltam a aparecer. Muito procurada, nos 5 anos que está no Brasil só namorou brasileiros e colombianos brancos, quase todos eles vindos "de fora". Como outras mulheres e jovens colombianas e brasileiras, incluindo algumas que participam ativamente nos mercados do sexo, não aceita facilmente a possibilidade de manter relações sexuais e afetivas com peruanos. Ela não diz o motivo, apenas nega com a cabeça e recolhe o nariz.

“O Brasil é uma mãezona!!!”, disse por fim, com tom negativo, uma mulher nos momentos finais da oficina na Universidade Estadual de Amazonas, enquanto outras tentavam relativizar com condescendência as vantagens para si mesmos da fronteira "aberta" e dos peruanos: "a gente pode comprar coisas em Leticia que se trazidas de Manaus seria muito mais caro..., "os peruanos vendem produtos muito baratos...” “...e tem ceviche!!”. A chocante e quase unívoca posição dos alunos concretizava a nossa percepção generalizada sobre o lugar que o Peru e os peruanos, ainda mais os loretanos, "indígenas" e pobres, ocupam nessa tríplice fronteira; mais ainda, deu literalidade emocionada e concentrada no tempo e no espaço ao modo como alguns brasileiros, colombianos e determinados peruanos se produzem performativa e contrastivamente enquanto mais ricos, mais brancos, mais atraentes, mais trabalhadores, com cheiros, feições e sonoridades melhores etc. Esse dispositivo social de produção de alteridades e desigualdades tem em seu centro uma ideia de nação atrelada de um lado à soberania, e de outro a princípios de "civilização" ou de desenvolvimento que operam em planos nacionais, regionais e étnicos: sobre o Peru, do 
ponto de vista do Brasil; sobre a Amazônia, em contraste com regiões nacionais tidas como mais poderosas, mais desenvolvidas e mais brancas; sobre os indígenas e "nativos", vistos por forasteiros e colonos. Chama-nos a atenção a recorrência desse dispositivo, pois é difícil encontrar brasileiros e colombianos, incluso indígenas, que não produzam discursivamente o Peru dessa maneira; portanto, ressalta a facilidade e diversidade de formas de expressão desse discurso, inclusive em planos acadêmicos e governamentais.

A construção desse dispositivo de desigualdade, que é também um princípio social de fronteirização, é tão forte que se atualiza também no âmbito do Estado na sua capilaridade ${ }^{10}$. De diversas situações possíveis para compreender essa atualização focamos uma vivenciada em conjunto e altamente significativa para nós três, pois cruzava questões das próprias pesquisas, do trabalho colaborativo conjunto e tem a ver diretamente com a capilarização de políticas federais, que também tem no centro ideias sobre "nação", "soberania", "fronteiras", "migração" e "direitos humanos". Nos referimos à chegada das políticas e dos discursos de enfrentamento ao "tráfico de pessoas" à tríplice fronteira no final de 2013 (OLIVAR, 2015). Até então não se tinha notícia de uma firme presença dessas políticas no local, ainda que desde 2010 a articulação entre tráfico de pessoas e territórios de fronteira estivesse sendo mais forte e explicitamente gestada no âmbito federal. A eficaz e duradoura capilarização dessas políticas/ discursos tem sido resultado do sistemático trabalho da Igreja Católica brasileira em coalizão com a colombiana e com algu-

\footnotetext{
${ }^{10}$ Na cidade de Amaturá, em 2012, um secretário municipal explicava à equipe do Observatório de Violência de Gênero no Amazonas que "peruanos são como ratos", em pouco tempo e espaço alastram-se e tomam conta de tudo; atualmente, discute-se na Câmara Municipal de Benjamin Constant um pré-projeto de lei que pretende obrigar comerciantes peruanos a empregar funcionários brasileiros no intuito de que parte da riqueza produzida por estes permaneça no Brasil posto que, segundo essa lógica, os comerciantes peruanos "ilegais" não pagam impostos, têm melhores condições de concorrência e remetem os lucros obtidos para sua terra natal, sem investir no país.
} 
mas lideranças locais, a partir da Campanha da Fraternidade de 2014, cujo tema era "Tráfico Humano" 11.

No início de dezembro de 2013 participamos de algumas das primeiras ações dessa Campanha em Benjamin Constant, articuladas com uma outra campanha de enfrentamento à violência contra as mulheres, liderada por algumas mulheres lideranças locais. As ações dessa segunda campanha incorporaram, rapidamente, a retórica da luta contra o tráfico de pessoas, particularmente de mulheres e menores brasileiras amazônicas e indígenas com fins de exploração sexual e foram associadas à problemática ampla da "violência contra as mulheres". Uma das ações consistiu em uma jornada de "sensibilização" em uma comunidade indígena próxima à cidade de Benjamin Constant, ministrada por funcionárias locais de saúde, direitos humanos e assistência social, membros do legislativo municipal, representantes da Estratégia de Estadual de Segurança Pública Integrada para a região de Fronteira e Divisas do Amazonas (ESFRON), mulheres lideranças sociais e integrantes da Igreja Católica que promoviam a Campanha da Fraternidade. No marco dessa jornada, entre espaços privados de conversa das ministrantes e os espaços públicos de "sensibilização", foram feitas pelo menos dez menções a peruanos (e colombianos-e-peruanos), incluindo "denúncias" e piadas, sem dados concretos, para exemplificar si-

\footnotetext{
${ }^{11}$ As políticas brasileiras de enfrentamento ao tráfico de pessoas podem ser consultadas no site do Ministério da Justiça. Enquanto crime está definido nos artigos 131 e $131 \mathrm{~A}$ do Código Penal Brasileiro. Por outro lado, é importante sublinhar que os princípios e metodologias dessas políticas, bem como as maneiras não sempre claras nem confiáveis como o conhecimento sobre tráfico de pessoas tem se produzido no Brasil, e os efeitos contraditórios e prejudiciais que têm mostrado no sentido de reprimir a prostituição e a migração, entre outras, são objeto de uma consistente crítica baseada fundamentalmente em pesquisa etnográfica; ver, por exemplo, Grupo DAVIDA, 2005; Piscitelli, 2011, 2008b; Teixeira, 2008; Blanchette\& Silva, 2012; Lowenkron, 2014; Sprandel, 2014; Piscitelli et ali, 2015. Apesar dessas críticas, continua sendo circulado e reproduzido conhecimento de tratamento bastante duvidoso que alerta sobre alguma realidade do tráfico de pessoas nunca comprovada, inclusive tendo como foco a Amazônia (TORRES E OLIVEIRA, 2012) e as fronteiras (BRASIL, 2013).
} 
tuações de violências e ilegalidades diversas que nesse contexto foram associadas à ideia de tráfico internacional de pessoas. E, claro, não houve nenhuma referência a brasileiros.

A partir daí, durante 2014 e 2015, ativistas laicos e religiosos vinculados à Igreja Católica junto com agentes dos direitos humanos e da assistência social, entre outros, realizaram diversas ações públicas de sensibilização e de prevenção ao tráfico de pessoas nos lados colombiano e brasileiro da fronteira. Sem nenhum cuidado com as categorias jurídicas e políticas, a "exploração sexual de meninas" foi o exemplo de "tráfico de pessoas" e o principal foco de atenções e emoções morais. 0 argumento geral, expressado por uma ex-funcionária colombiana de Bienestar Familiar, era que falar de "explotación" ali implicava falar em "trata" (tráfico de pessoas) pela fronteira "abierta" e pela intensa mobilidade transfronteiriça. Nas palavras de uma agente da Igreja em Tabatinga, essa exploração, "prostituição de meninas", seria o principal problema associado ao tráfico de pessoas.

A escolha desse foco pela coalizão religiosa, civil e governamental brasileiro-colombiana, implicou o direcionamento do olhar vigilante em pessoas, locais e territórios específicos. A ativista religiosa antes mencionada, em entrevista realizada em dezembro de 2013, identificava a ilha peruana de Santa Rosa como o lugar privilegiado para "ver" esse tráfico acontecer, e uma liderança feminina benjaminense, já sensibilizada no "Tráfico $\mathrm{Hu}$ mano" pelos agentes da igreja, exigiu pessoalmente de um representante da Marinha do Brasil maior controle e repressão na mobilidade fluvial entre os lados brasileiro/colombiano e peruano, especialmente de adolescentes e em horários noturnos, pois segundo ela, seria muito comum ver chegar de madrugada no porto de Tabatinga e de Leticia a meninas bêbadas, cortadas, que teriam sido exploradas "no Peru", leia-se Santa Rosa (como exemplo de tráfico internacional de pessoas). 


\section{A migração peruana na Amazônia brasileira}

A “migração peruana na Amazônia brasileira” tem sido objeto de produções acadêmicas no Brasil, fundamentalmente desde análises sociológicas muito preocupadas com marcadores nacionais (Peru e Brasil, por exemplo), com dados censitários, com formas de discriminação e exploração, e com exigências de regulações governamentais. Oliveira (2008, 2010), Silva (2010), Santos (2012) e Jakob (2011) são autores representativos dessa perspectiva ${ }^{12}$. Seus trabalhos adotam "migração" como categoria de análise para compreender presenças, deslocamentos e mobilidades peruanas através da fronteira nacional e no espaço amazônico. Interessa-nos aqui refletir sobre os usos e implicações potenciais desse tipo de análise para os fenômenos em questão.

A presença peruana no Brasil é expressiva, como demonstram os dados censitários analisados por Jakob (2011). De acordo com o autor, o Peru ocupa a segunda posição entre os países de origem dos "imigrantes" que chegam ao país. Desses, uma importante parcela (aproximadamente 30\%) tem como destino a Amazônia Brasileira, especialmente as cidades de Tabatinga (9,53\%), Benjamin Constant (6,96\%), São Paulo de Olivença (6,44\%), Atalaia do Norte (3,59\%), Santo Antônio do Içá (1,9\%) e Tonantins $(1,24)$. (Jakob, 2011, p. 429).

Importante destaque faz o autor à dificuldade de apreensão e aferição do que denomina "processos migratórios", expressão empregada com referência aos estudos de Pellegrino (JAKOB, 2011, p. 423) para quem o "processo migratório" na América Latina cumpriu quatro etapas sucessivas: a colonização europeia no século XVI, a emigração europeia ocorrida nos séculos XIX e $\mathrm{XX}$, o êxodo rural para grandes metrópoles entre as décadas de

12 É preciso levar em consideração que todas essas pesquisas são anteriores ao ingresso do Peru, da Bolívia e da Colômbia no Acordo Mercosul que facilita a permanência regular de nacionais destes países no Brasil (Decreto $n^{\circ} \mathbf{6 . 9 7 5}$, de 7 de outubro de 2009.). 
1930 e 1960 e a emigração da América Latina para os Estados Unidos entre 1970 e 2000. É durante a terceira etapa que Pellegrino identifica o processo de migração internacional de "caráter regional e fronteiriço", manifesto, por exemplo, no ingresso de peruanos na Amazônia Brasileira. Note-se que a perspectiva de Pellegrino usada por Jackob é marcadamente linear e homogeneizante, articulando fenômenos sociais e políticos profundamente diferentes como parte de uma mesma categoria e em sequência linear.

A motivação econômica ocupa importante papel na matriz explicativa dos processos migratórios para esses autores. A posição economicamente ascendente do Brasil e o poder de atração exercido frente a outros países da América Latina configura-se, para Jackob e outros autores (OLIVEIRA, 2008, 2006; SANTOS, 2012), como a explicação privilegiada para a imigração na Amazônia brasileira, possível pelo que alguns autores entendem como uma fácil mobilidade amazônica através das fronteiras, ou "o crescente processo migratório intrarregional e fronteiriço que, a um passo, está-se em outro país" (TORRES e OLIVEIRA, 2012, p. 24)

A pobreza e falta de oportunidades econômicas nos países de origem continuam sendo uma explicação persistente e uma imagem abrangente dessas migrações, que são interpretadas como obrigadas (OLIVEIRA, 2010) ou compulsórias. Nos termos de Oliveira (2008), por exemplo, a "mobilidade compulsória”, principal característica para essa autora dos deslocamentos colombianos e peruanos na tríplice fronteira, resulta da estrutura neoliberal (SANTOS, 2012) que expulsa os segmentos mais pobres da população peruana para países como o Brasil. No caso dos colombianos, para a autora, está a guerra e as perseguições políticas definindo a condição compulsória (OLIVEIRA, 2010).

Embora também para essa autora a abordagem econômica desempenhe papel determinante para as motivações da migração, 
os segmentos mais pobres da população peruana atraídos pelo Brasil não parecem representados no perfil descrito por Jakob, no qual a população peruana no país, a maioria composta por homens adultos (52,2\%), com média de 11,2 anos de estudo e renda mensal superior a nove salários mínimos, aparece melhor posicionada social e economicamente que os "imigrantes" provenientes da Bolívia, Colômbia e Paraguai. A aparente contradição entre os dados econômicos desses dois autores sugere a necessidade de outros recursos conceituais para compreensão de diferentes regimes de mobilidades, experimentados no cotidiano da tríplice fronteira e permitirão, quiçá, apreender outras nuanças dos fenômenos estudados.

Ao retratar os peruanos residentes no Brasil em perspectiva qualitativa, as imagens evocam não raras vezes a sua pobreza, o que pode estar associado ao modo como Brasil e Peru são vistos no cenário econômico da América Latina, como argumentam os autores em tela. Nessas descrições são usadas imagens que remetem à miséria, ao "subdesenvolvimento" do Peru (OLIVEIRA, 2010), a condições de "exploração", incluso entre conterrâneos (OLIVEIRA, 2006, p.160), e a grandes périplos de comércio de quinquilharias e de trabalho braçal pouco qualificado (SILVA, 2010, p.207). Essas condições econômicas, no contexto histórico das pesquisas aqui referidas, estavam marcadas também pela difundida condição migratória irregular em que muitos peruanos se encontravam na Amazônia antes da efetivação do Acordo Mercosul de 2009 (Ver nota 8).

A literatura especializada, então, tem descrito as condições de pobreza e a falta de garantias de direitos nos países de origem como causas de migrações internacionais que são apresentadas como compulsórias e que se tornam mais tortuosas devido às anteriores restrições migratórias impostas pelo Brasil. Essa literatura construiu uma imagem de diferenciação contrastiva nacional bastante marcante, que coloca o Peru em uma condição social, econômica e política bastante inferior ao Brasil e, por- 
tanto, a "os peruanos" como sujeitos vulneráveis. Desse modo, a literatura especializada produziu uma importante solidariedade política com os migrantes peruanos, particularmente, reivindicando para eles um lugar de precariedade econômica e política que favoreceria a solidariedades social e o seu reconhecimento enquanto sujeitos de direitos e, portanto, destinatários de políticas públicas diferenciadas (OLIVEIRA 2006, 2008, 2010; SILVA, 2013, 2010).

Essa solidariedade é reconhecida na história de regularização de um migrante peruano no trabalho de Oliveira (2010, p. 21) e foi articulada por outros "conterrâneos" pelo caminho dos "direitos humanos". A autora afirma que "conseguiram contato junto à Comissão de Direitos Humanos e foram aceitos. Tendo, hoje, acesso à educação, à saúde, os próprios brasileiros passaram a valorizá-los. Hoje ele está muito feliz".

Um problema dessa construção é que no imaginário popular, a visão dos peruanos como pobres, subdesenvolvidos e irregulares, antes de representar piedade, identidade ou solidariedade, parece aproximar-se mais da repulsa, rejeição e repressão, posto que assevera a condição de disputa face à suposta escassez de recursos públicos que caracterizaria para muitos agentes sociais e políticos a região analisada. Esse imaginário será objeto da sessão seguinte; porém, antes de avançar é importante prestar atenção a como em produções acadêmicas locais da Universidade Federal do Amazonas em Benjamin Constant essa visão de diferenciação contrastiva e de franca desigualdade ou discriminação se faz presente ou é objeto de estudo. Para isso comentaremos brevemente os trabalhos de Oliveira (2010) e de Campos (2012), ambos anteriores à efetivação do ingresso do Peru ao Acordo Mercosul com o Brasil.

O trabalho de Oliveira (2010) sobre a presença peruana no comércio da cidade brasileira de Benjamin Constant mostra como, num marco regulatório restritivo da migração operacionalizado 
pelo Estado e associado à gestão social da condição de "ilegalidade" ou de sujeitos "não documentados", a ideia de imigração pode constituir-se uma barreira para melhor estimar e compreender a população peruana no contexto e fenômenos aqui considerados. No trabalho dessa autora, a ideia de imigração aparece associada à de ilegalidade, acionada frequentemente por seus interlocutores, comerciantes peruanos entrevistados durante a pesquisa, mas também pela autora. A estigmatização desses sujeitos é também sugerida na menção à rejeição e desvalorização de peruanos por brasileiros. 0 temor imposto pela situação de ilegalidade também é manifesto no incômodo e recusa em participar da pesquisa.

A minha irmã tem permanência, porque vocês querem me entrevistar, eu estou ilegal no Brasil, viajei para regularizar, mas não deu certo. 0 meu pai veio me visitar e me deu muitas broncas, disse que não é para eu responder nada e deixar para minha irmã tomar a frente de tudo, pois parece que tá ficando preocupante minha permanência aqui na fronteira. (OLIVEIRA, 2010, p.25).

Outro aspecto relevante presente no trabalho de Oliveira (2010) diz respeito à representação muito frequente em moradores de Benjamin Constant da "migração" peruana na tríplice fronteira associada às "vantagens" e aos usos "oportunistas" da dita ilegalidade. Essa visão tem um lugar especial nas arengas sobre o baixo custo dos produtos peruanos que são depois revendidos no Brasil e sobre o não pagamento de impostos por parte de peruanos "Não porque se esquivam em pagar, mas por não ter uma cobrança superior" (p.32). Na perspectiva de alguns benjaminenses entrevistados por Oliveira (2010), esse oportunismo situa nacionais e peruanos em constante oposição e concorrência, na qual os brasileiros se descrevem como estando invariavelmente em desvantagem, pois nas suas queixas pagariam impostos, seriam fiscalizados pelo Estado e seriam obrigados 
a dividir com os "estrangeiros" os serviços públicos ostensivamente descritos como escassos.

Por outro lado, Ana Maria de Mello Campos (2012) oferece valiosas narrativas, ao redor da atenção em saúde a grávidas peruanas oferecida em Benjamin Constant, das quais destacamos apenas uma altamente significativa.

Eu faço o que meu chefe manda. Porque você não vai em Islândia investigar se essas mulheres tem dupla nacionalidade? Você está incentivando que a malandragem se estabeleça aqui, investigando se atendemos ou não as peruanas. A grávida peruana que vai na minha unidade, é atendida, mas não entrego de jeito nenhum a carteira de gestante, porque a Secretaria de Saúde orienta assim (Enfermeira A). (22)

Na busca por acesso a serviços e direitos, incluída a busca pela universalidade do SUS, o panorama de desprezo visível nas narrativas de agentes de saúde levantadas por Campos (2012) é extremamente pesado e se usa de acusações morais como "malandragem", de normatividades etéreas sobre saúde e sobre migração e de obediências devidas para se justificar. Segundo a autora, a resistência para atender essa população chega ao extremo de colocar em risco a vida da mãe e do filho. Inclusive, a própria pesquisadora se transforma em uma ameaça, voltando-se sobre si a agressividade de duas das interlocutoras e uma suspeita por parte das autoridades de saúde que ultrapassou seu trabalho acadêmico.

Por fim, um aspecto ressalta no trabalho de Campos (2012) que se distancia de boa parte da bibliografia anteriormente referida e nos abre o caminho para a seguinte sessão e para a nossa proposta de discussão. Perguntando-se sobre a atenção às peruanas, a autora está menos interessada na "migração" peruana que na produção contrastiva e hegemônica de um de- 
terminado Brasil nessa relação e nesse lugar. De fato, diferentemente de boa parte da bibliografia discutida acima, "migração" não ocupa um lugar especial nos dados nem nas análises de Campos. É uma certa perspectiva estatal e social brasileira sobre a presença peruana a que ocupa detalhada e etnograficamente a atenção da autora, e é nessa atenção que malandragens e vitimizações nacionais aparecem como elementos discursivos do enredo e não como categorias explicativas da relação. Nesse sentido, é interessante a opção da autora em denominar essa relação de discriminação como "racismo" e não xenofobia, esvaziando a categoria "nação", que parece ser tão importante para os demais atores no seu campo, na produção acadêmica e nas políticas públicas.

\section{Reconfiguração: presenças e mobilidades transf ronteiriças.}

$\mathrm{Na}$ nossa experiência de habitar e pesquisar essa tríplice fronteira, o enredo anteriormente apresentado sobre os peruanos não encontra explicação suficiente nos estudos centrados em "migração", de um lado, e em "nação", do outro, como categorias analíticas ou explicativas das discriminações ou das experiências de grupos ou sujeitos particulares nessa tríplice fronteira. É pouco o que essa abordagem tem a dizer, por exemplo, sobre a brasilidade dos participantes da oficina, ou sobre suas trajetórias de migração "interna" atreladas às dos peruanos. Nesse estilo de abordagem, é frequente deixar de fora questões de interseccionalidades, de produção da alteridade, de circulações ou deslocamentos intranacionais ou intrarregionais, de agência e auto-organização, de operação prática capilar do Estado, entre outras. Essa escolha teórica, como vemos, apaga uma vasta pluralidade de experiências ao mesmo tempo que corre o risco de reproduzir discursos sobre a nação, a fronteira e a migração como princípios de poder e de governamentalidade constituintes de discriminações e desigualdades. Assim sendo, na presente sessão propomos uma 


\section{abordagem teórica alternativa para futuras pesquisas centra- da na fronteira e no território transfronteiriço como experi- ências sociais (e não na nação como categoria analítica) e na ideia consequente de regimes de presenças e de mobilidades em e através destas.}

Nesse tempo primeiro não tinha Peru, Brasil, Colômbia, assim como a gente tem hoje. Era só terreno Ticuna, não tinha isso de documento, [de nacionalidade]. Gente nossa ia e vinha. Não tinha essa palavra de terra indígena, de fronteira. Ia-se e voltava por esse rio. (...) Foi depois das guerras, da chegada dos missionários, dos brancos, dos militares, do $\mathrm{SPI}^{13}$, das igrejas. Foi nessas misturas de saberes sobre esse lugar, que nos separam tudo assim: lá Leticia, as aldeias de Laranjal, Arara, Macedonia; lá Tabatinga, Benjamin Constant, São Paulo de Olivença, Amaturá as comunidades de Umariaçu, Filadélfia, Campo Alegre, Nova Itália, Santa Inês, Betânia, Vendaval; e lá do outro lado, Caballococha e as aldeias dos parentes que ganharam nome de peruanos. Misturou tudo: índio, gringo, colombiano, brasileiro e peruano nesse rio agora com lado e nome de países. (...) e misturou para separar de novo os parentes, só que de outro jeito, nesse tempo mais de agora. Mas a Lei do branco que divide os povos, não divide assim os Ticuna do mesmo jeito. Não tem papel [documento] assim que proíbe de ir e voltar, né? A lei do índio é fazer esses movimentos, de passeio, de visita, de reunião, de venda, de namoro... tudo assim, sem isso de fronteira, como dizem ai. A gente diferencia os parentes por outras coisas, né. Só que prá entender disso, tem de contar dessas histórias que vem junto com a história do nosso povo. (...) É assim, dona, sabendo dessas diferenças entre os parentes e com os nossos awane [inimigos], é que a senhora

\footnotetext{
13 Serviço de Proteção ao Índio, órgão tutelar do estado criado em 1910, foi desmantelado em1967, dando origem à Fundação Nacional do Índio (FUNAI). O SPI teve seu primeiro posto de controle no Alto Solimões alocado Tabatinga, em 1942, organizando no seu entorno a comunidade Ticuna de Umariaçú. De acordo com Oliveira Filho (1988) a ação do SPI foi marcada por contradições identificadas como "paradoxos indigenistas", pois tinha por objetivo respeitar as terras e a cultura indígena, mas atuava transferindo índios e liberando territórios indígenas para colonização, impondo uma pedagogia que alterava todo o sistema produtivo indígena.
} 
vai ir conhecendo os porquês de dizermos por aí que casar melhor com gente desse lado do rio. (...)

A fala do interlocutor Ticuna concatena algumas ideias gerais aqui expostas sobre como diversas "nações" reivindicam e reivindicaram por séculos hegemonias, fronteiras, direitos e origens sobre essa terra. Contudo, não se trata apenas de narrativas sociocosmológicas sobre a terra original pré-hispânica ou pré-estatal, mas de memórias, tensões, invenções, improvisos e disputas históricas cotidianamente atualizadas sobre, entre e contra a larga linha fronteiriça, nas quais ideias e práticas sobre "movimento", "permanência" e "presença" são centrais. Nesse sentido, a "nação", se transforma em um privilegiado objeto de disputa e numa ferramenta de governamentalidade ${ }^{14}$.

A tríplice fronteira entre Brasil, Colômbia e Peru, que tem como vértice de confluência a cidade transfronteiriça de Tabatinga/ Leticia/Santa Rosa no Alto Solimões/Amazonas, é muito mais do que o espaço político administrativo limítrofe de três estados-nações. Desde uma perspectiva histórica e antropológica, essa tríplice fronteira vai muito além destas linhas divisórias e seus vértices e se constitui num vasto, diverso e intenso espaço social e político transfronteiriço. Seguindo a proposta de Zárate $(2008,2011)$, de colocar a fronteira (território, processo, "opção interpretativa") no centro do estudo histórico dessa região amazônica, conseguimos ver uma dinâmica social e política que simultaneamente ultrapassa as histórias nacionais (nação como contendora de uma história) enquanto dá à produção da nação e, por tanto, do Estado, da fronteira, da "cultura", uma singular relevância (nação como conteúdo a ser preenchido empiricamente).

${ }^{14}$ Sobre a história da região e do processo de fronteirização ver: Oliveira Filho, JP. (1988); Oliveira, Roberto Cardoso (1972); Goulard (2010); Zárate (2008); Taussig (1993). Sobre a cidade: Picón (2012); Aponte (2011); Pantevis (2013). 
Essa história, que não podemos detalhar aqui, é a história das disputas imperiais primeiro e republicanas depois pelos limites não apenas das suas terras, mas das suas imaginações e das suas capacidades de evangelização, exploração, civilização e conquista, que se estendem desde o século XVI até bem entrado o século $\mathrm{XX}$, e implicaram o deslocamento de ida e volta através do rio Amazonas tanto de bandeiras imperiais/nacionais quanto de línguas, de agentes estatais e de habitantes indígenas e colonos (PINEDA, 2011; ZÁRATE, 2011). Por esse caminho entendemos que "estado" e "nação" não apenas são categorias extremamente novas e instáveis, mas armas de colonização, de contraste e de controle de populações nativas e forasteiras em histórico e constante movimento.

A história de Tabatinga e de Leticia, e da sua "conurbação", analisada por Aponte-Mota (2011) é bastante exemplar nesse processo, pois coloca o Brasil e a Colômbia numa posição institucionalmente melhor e, permanentemente, diferenciada dos sempre presentes e anteriores peruanos. É só a partir dos anos 1930 que Leticia deixa de ser peruana e passa a ser colombiana, implicando um processo de nacionalização da população, de migração colombiana a essa cidade e de altos investimentos institucionais colombianos se comparados com os peruanos. Por outro lado, está o processo recente de urbanização de Tabatinga a partir da sua municipalização em 1983. Don Simón, um comerciante peruano próximo dos 80 anos que tem um posto de venda de produtos agrícolas na região da feira, em Tabatinga, contava que trinta anos atrás “aquí no había nada!”, era "puro monte", umas poucas casas e poucas ruas de barro. Foi nessa época, coincidente também com uma bonanza regional da cocaína que teve em Letícia seu foco comercial, que o exército brasileiro, ele lembra, recrutou as pessoas que já habitavam e trabalhavam ali para construir e povoar a nascente cidade. Don Simón afirma que o exército brasileiro, do qual em 2012 fazia parte seu filho, deu as terras a pessoas cujos origens nacionais eram desconhecidas ou subordinadas à simples pre- 
sença e ao trabalho no local, e ajudou na construção de ruas e de serviços públicos ${ }^{15}$.

Experiências como a de Don Simón servem para nos aproximar aos limites de uma abordagem teórica antropológica desde as migrações. Nina Glick Schiller e Noel Salazar (2012) chamam a atenção sobre os recentes "estudos de mobilidade" como um corpo crítico aos estudos de migração mais clássicos, entre os quais poderíamos enquadrar boa parte da bibliografia antes referida sobre a "migração peruana". Esse corpo crítico se opõe à oposição autoexcludente entre mobilidade e estatismo [mobility and stasy], entre mobilidade e sedentarismo que, segundo os autores, marcou os estudos de migração até o final dos anos 1990, e suporia o sedentarismo como norma, fazendo das migrações uma espécie de eventos excepcionais circunscritos a momentos "compulsórios" e razões específicas como a "pobreza". Efeito dessa leitura binária e oposicional é a concepção da migração (e da fronteira assim metaforizada) como evento altamente marcado por valores morais, emocionais e políticos: migração como ameaça, migração como liberdade, fronteira como bloqueio ou como fluxo, entre outros.

Ainda segundo Schiller e Salazar (2012), um dos principais problemas detectados nos estudos de migração por eles contemplados é o "nacionalismo metodológico": “...uma orientação ideológica que aborda o estudo de processos sociais e históricos como se estes fossem contidos dentro de fronteiras de estados-nações

${ }^{15}$ Perspectivas peruanas não tem sido o objeto principal deste artigo; porém, a voz de Dom Simón era necessária para melhor compreender as presenças peruanas transfronteiriças. Vários peruanos e colombianos que têm negócios em Tabatinga compartilham a ideia de que "no Brasil" (leia-se Tabatinga, mas também outras cidades e comunidades do Alto Solimões) as pessoas não precisam trabalhar; "viven del gobierno, que les da todo" e são donos dos locais comerciais alugados e trabalhados por peruanos. Nessa lógica, e seguindo observações e diversas conversas de campo, a força de trabalho não qualificada e a base do comércio em Tabatinga seria peruana; enquanto a propriedade continua sendo principalmente brasileira. 
individuais" (Schiller \& Salazar, 2012: 3). Essa crítica aponta ao uso de "nação", "etnia" ou "religião" como categorias analíticas ou explicativas de práticas e de fenômenos sociais, o que implica, de um lado, a não problematização de ideias êmicas sobre "ethos nacionais" e, por outro lado, reforça a presença do estado-nação (em documentos e linhas divisórias) como parâmetro e baliza na compreensão dos movimentos migratórios.

Schiller e Salazar (2012) avaliam que os "estudos de mobilidade" tem tornado mais complexas as relações entre mobilidades e inercias, e a relação entre pessoas, regimes migratórios e marcadores de identidade, além de levar em maior consideração relações transnacionais de poder, ambiguidades e ambivalências, simultaneidades, articulações entre regimes migratórios diversos, entre outras, (Schiller \& Salazar, 2012). Tal aposta dos autores pela "mobilidade" se traduz de um lado no recurso analítico de "regímenes de mobilidade" e do outro no foco de Schiller sobre "cidades transnacionais" (2010), que implica a atenção a presenças e permanências transnacionais.

Na produção brasileira recente sobre migrações e mobilidades esse estilo de análise encontra ricas contribuições em trabalhos como os de Bela Feldman Bianco (2009), sobre migrações portuguesas nos Estados Unidos, bem como no trabalho de Adriana Piscitelli (2013) e de Paula Togni (2014), entre outras. Particularmente nas pesquisas dessas duas últimas autoras com migrantes brasileiras/os na Europa, na relação da mobilidade com gênero, sexualidades, parentesco e dinheiro, elas têm atentado às tensões empíricas, aos deslizamentos e aos usos táticos de categorias como nação, cor, geração e classe, em articulação com gênero. Um importante efeito desses trabalhos é problematizar as imagens tanto de hiperssexualização como de vitimização e vulnerabilidade que recorrentemente se construí sobre "a brasilidade". Nesses mesmos trabalhos, os Estados aparecem como agentes polimorfos com participações que vão para além da restrição migratória e em diversas relações com outros agentes 
sociais e com outros agentes de governamentalidade, mas que tem nessa posição de controle e governo uma participação privilegiada.

O destaque de Schiller e Salazar sobre a não excepcionalidade da migração e da mobilidade tem um correlato na produção brasileira especialmente importante; trata-se das análises de André Dumas Guedes sobre "movimentos" e "durações" no norte de Goiás (2013). Revisando uma clássica literatura brasileira sobre grupos populares e campesinato em relação com seu extenso trabalho de campo em Minaçu (GO), o autor afirma a ideia de que o movimento, a andança, longe de ser uma excepcionalidade ou resultado puramente de condições estruturais, se constitui numa caraterística sociológica e histórica de muitos grupos humanos populares e rurais no Brasil. A partir dessa ideia, o autor elabora toda uma teoria nativa que tem no centro a tensão entre os opostos "movimentos" e "durações", mobilidades e permanências que não são transnacionais, que não são ordenadas e nem explicadas apenas por constituições nacionais ou por decisões de Estado, e que atravessam integralmente as vidas e as trajetórias desses sujeitos.

Finalmente, é importante chamar a atenção para a ideia de transfronteiriço. A maior parte da produção sobre mobilidades está atenta a deslocamentos e relações transnacionais, mas o nosso caso nos exige pensar em termos de um espaço social configurado em, por e através de fronteiras que, já vimos, implicam sobreposições, articulações e multiterritorialidades (HAESBAERT, 2011). Nesse sentido, resulta útil para os nossos propósitos prestar atenção a como a questão do transfronteiriço, da nação e das mobilidades é compreendido no campo específico da etnologia. Se são parcas as etnografias focalizando o tema da "migração" indígena peruana na tríplice fronteira, do contrário observa-se um esforço analítico para compreender os modos de vida nos espaços transfronteiriços, especialmente pela abordagem das conexões entre fronteiras, "identidade étnica" e "nacionalização 
das populações indígenas", como colombianos, peruanos e brasileiros. Nesse sentido, trabalhos como os de Cardoso de Oliveira (2001), López Gárcez (2000, 2011), Chaumeil (2000), Goulard (2005) e Reis (2013), entre outros, ocupam-se em descrever a mobilidade indígena na região, vista como "zonas de contato" e "intercâmbios". Esses autores, grosso modo, sublinham que a mobilidade e a dinâmica identitária que caracteriza esse espaço transfronteiriço operam a partir da sua utilização estratégica por diferentes populações indígenas (Ticuna, Cocama, Yagua, Matses) e não indígenas (mestiços, migrantes andinos, agentes indigenistas, missões religiosas, órgãos indigenistas do Estado, ONGs, pesquisadores), trazendo a complexidade de suas dinâmicas próprias.

Outra referência útil no sentido de dar ao transfronteiriço um estatuto que não é apenas de recorte empírico, no sentido do proposto por Guedes através da noção espaço-temporal de "movimentos", é o livro "Transborder Lives", de Lynn Stephen (2007), no qual a autora analisa o espaço social construído por redes de pessoas identificadas como Mixtecos e Zapatecos, que se estendem desde as terras natais no México até cidades norte-americanas. A autora usa uma noção de "fronteira" que se desliza entre o êmico e o analítico, pois se o ponto de partida é o deslocamento através da fronteira internacional, a sua proposta recolhe claramente elementos analíticos de "fronteira". Para ela, as fronteiras que seus protagonistas "atravessaram e continuam a atravessar são muito mais que nacionais" (23).

Quando Mixtecos e Zapatecos vem nos Estados Unidos, eles estão atravessando um novo conjunto de fronteiras regionais que são usualmente diferentes daquelas no México, mas que podem se sobrepor com aquelas no México (...). Estas incluem fronteiras étnicas, culturais e regionais dentro dos Estados Unidos. Por tais razões, tem mais sentido falar em migração transfronteiriça no caso que estou descrevendo aqui, que simplesmente transnacional. 0 
transnacional termina sendo parte da experiência transfronteiriça. (STEPHEN, 2007, p. 23).

A proposta de Stephen é relevante para o nosso caso de estudo, porque trata sobre redes de migrantes que estão em constante mobilidade e rearranjo, e que desde há já algumas gerações construíram o seu "espaço social" não tanto no vínculo entre duas nações, mas no atravessar e circular por entre uma série de fronteiras. Do mesmo modo, ela chama a atenção para tudo o que acontece nesse espaço - social, temporal e geográfico - chamado fronteira, que se estende por entre emaranhados de relações até as casas e os corpos dos migrantes e dos não migrantes. Esse espaço/tempo entre um lugar e outro que, como afirma Dias (no prelo), tem sido relativamente esquecido em muitos estudos sobre migrações brasileiras, a pesar da sua fundamental importância.

No nosso caso, diferentemente do estudo de Stephen, não há no meio destas redes de migrantes uma das mais fechadas e vigiadas fronteiras do mundo (a fronteira México-EUA); muito pelo contrário, trata-se de um território cujos controles fronteiriços se mostram significativamente frouxos e concentrados nos principais pontos de embarque fluviais e aéreos. Seguindo genealogias e redes de relações familiares e afetivas (parentesco, "relatedness"), intercâmbios econômicos e sexuais recorrentes, presenças e mobilidades, e usos táticos de marcadores de diferença, o território transfronteiriço se abre para além das linhas limítrofes e da cidade tríplice ${ }^{16}$. Para exemplificar apenas a partir da metáfora territorial, esse enfoque nos permite ver um espaço social transfronteiriço, que inclui as cidades brasileiras da mesorregião do Alto Solimões e outras como Vila Betancourt (na

\footnotetext{
${ }^{16}$ Ver Yagüe (2013) sobre redes de alimentos de indígenas habitantes de Leticia, também Victorino (2012) sobre o "nodo transfronteiriço" do rio Caquetá/Japurá. Ver Rodrigues e Pereira (2012) para um panorama de migrações e mobilidades na Amazônia setentrional; Silva $(2010,2013)$ sobre migração peruana, colombiana e haitiana em Manaus.
} 
fronteira Brasil-Colômbia sobre a linha Tabatinga-Apaporis), cidades peruanas, como Islandia, Caballococha, Pebas e Cuchillococha, colombianas, como Puerto Nariño e Tarapacá, entre outras, além de dezenas de comunidades indígenas e de "colonos", tanto ribeirinhas quanto de "terra firme", que conectam importantes rios, além do Amazonas/Solimões - como o Putumayo/ Içá, o Yavarí/Javari, o Caquetá/Japurá. Essa interpretação panorâmica a partir dos fluxos, intercâmbios e mobilidades, nos leva facilmente até as cidades de Iquitos (Peru) e Manaus (Brasil), sobre o rio Amazonas e à Bogotá (Colômbia) com fácil e intensa conexão aérea, para não ir mais longe, o que implicaria pensar essas cidades como fronteiras sociais frouxas do território transfronteiriço (os limites desse território estão dentro dos países).

Se as dinâmicas e o processo de fronteirização nos servem para entender que as presenças e mobilidades transfronteiriças não se reduzem à migração - da maneira como é apresentada na literatura discutida e como é, em outro plano, criticada por Schiller e Salazar (2012) -, também nos servem para entender a produção das assimetrias econômicas e políticas articuladas a essa relativamente livre mobilidade transfronteiriça, e à afirmação crescente dos Estados nacionais: a "desigualdade" à qual se referiam os estudantes da UEA (Universidade Estadual do Amazonas) durante a oficina e a "pobreza" dos peruanos referida nos estudos inicialmente descritos. Enquanto os estados brasileiros e colombiano enfocaram seus investimentos a partir dos anos 80 na ampliação urbana e institucional em Tabatinga/Leticia, o estado peruano concentrou seus investimentos urbanos, estatais e econômicos amazônicos em cidades como Iquitos e Pucallpa, significativamente distantes da linha fronteiriça. Desse modo, o Peru não conta com uma infraestrutura estatal nem com uma organização urbana e econômica comparável nessa fronteira com as dos outros dois países. Essas decisões de estado e esses processos sociais e econômicos têm um correlato na produção étnica/racial como vetor contrastivo e de produção de desigualdades. Isto é, a presença brasileira e colombiana na região está 
fortemente marcada por um processo de urbanização e de "civilização" que tem uma base importante na migração interna de comerciantes, empresários, missionários, ambientalistas, professores, militares, funcionários públicos civis, entre outros não-indígenas e não amazônicos. Essas dinâmicas contrastam com a peruana, estatalmente mais concentrada no eixo Iquitos-Pucallpa, e muito mais centrada em mobilidades regionais informais de trabalhadores não qualificados e, aos olhos dos "brancos", com fortes ancoragens indígenas.

Esse arranjo histórico, que não é apenas nacional, mas fronteiriço, em um contexto regional de urbanização, de aumento devido dos serviços públicos e de bancarização da economia implica que a população da região, independentemente das nacionalidades ou pertencimentos étnicos, busque crescentemente as cidades. Essa dinâmica coloca a cada um dos países-em-fronteira em lugares particulares. 0 Brasil-na-tríplice-fronteira assume uma interessante posição na produção dos desejos se levarmos em consideração, de um lado, os altos investimentos brasileiros recentes em se afirmar como uma potência econômica regional, incluindo o aumento de benefícios sociais e de redistribuição de renda e a manutenção da saúde e da educação públicas, do outro lado, a alta presença de demanda comercial devido à massa de funcionários públicos municipais, estaduais e federais comparativamente melhor pagos e em melhores condições laborais, e, por último, a ainda escassa e precária fiscalização policial/militar, migratória e tributária.

A descrição anterior implica a existência histórica e contemporânea de toda uma vida social, política e econômica tecida nas mobilidades e nos "movimentos" através de múltiplas fronteiras, também nacionais, e na produção e disputa destas e dos territórios associados. Nesse sentido, como é visível na pesquisa de Albuquerque com "brasiguaios" (2010) ou na já referida pesquisa histórica de Zárate (2008, 2011), "transfronteiriço" recompõe a nação e o social desde um outro lugar, o lugar da fronteira, e tem 
muito mais a ver com um conjunto de relações práticas, históricas e cotidianas, também relativamente territorializadas, do que com políticas de "harmonização de fronteiras" ou com territórios política, cultural e legalmente constituídos como bi ou trinacionais.

\section{Considerações Finais}

A partir da nossa experiência multiposicionada de pesquisar e habitar a tríplice fronteira entre o Brasil, a Colômbia e o Peru identificamos um importante enredo social e relacional, local/ transfronteiriço, sobre as mobilidades e presenças peruanas nos olhos e nas terras brasileiras. Esse enredo diz respeito à necessidade social generalizada de identificar, localizar e qualificar - negativamente - aquelas pessoas, produtos ou espaços peruanos. Na primeira sessão do artigo descrevemos esse enredo através de dados etnográficos em termos de um consistente sistema de produção de diferenças e de desigualdades que tem seu pivô em ideias de procedência/pertencimento nacional, regional e étnico, e que coloca os peruanos, principalmente amazônicos ("loretanos"), na posição social mais baixa, ora como sujeitos de permanente suspeita e desprezo, ora como vítimas da pobreza e dos marcos regulatórios. Nesse registro, tomando como referente etnográfico a chegada à fronteira da política de enfrentamento ao tráfico de pessoas, mostramos como esse sistema permeia o âmbito do Estado, das políticas públicas e das governamentalidades. 0 nosso foco, seguindo o exemplo de Campos (2012), foram as percepções brasileiras sobre "o Peru" e "os peruanos" e não as experiências de migrantes peruanos, o que nos permitiu entender como esse Peru-na-fronteira "pobre", "malandro", "perigoso" e "necessitado" - e no contraste o Brasil - é produzido cotidianamente. Porém, levamos em consideração também como esse sistema descrito é também reproduzido, manipulado e usado taticamente por pessoas identificadas como peruanas e "loretanas" para criar novas distinções (regionais e étnicas intranacionais) e para construir ganhos simbólicos. 
$\mathrm{Na}$ busca por referentes bibliográficos locais que nos permitissem uma maior compreensão do fenômeno em questão, revisamos uma literatura especializada produzida no Brasil que tem focado na "migração peruana na Amazônia brasileira" e que foi apresentada na segunda sessão do artigo. Vimos como essa literatura foca privilegiadamente em análises sociológicas muito preocupadas com marcadores nacionais (Peru, Brasil), com dados censitários, com formas de discriminação e exploração, e com exigências de regulações governamentais. A principal variável considerada por essas pesquisas para explicar a migração internacional de peruanos ao Brasil é a pobreza vivida por estes migrantes e as desigualdades econômicas regionais que resultariam numa saída relativamente "compulsória" dos nacionais de determinados países em busca do emergente Brasil. Apesar de que essa literatura tem avançado na construção do problema e tem construído uma importante solidariedade política com migrantes estrangeiros no Brasil, quando a contrastamos com os nossos dados, resulta curta. Em particular, vimos como a ideia de "migrante" não facilita a compreensão de presenças históricas, emaranhadas e diversas, do mesmo modo que o diferencial "internacionais" implica o isolamento de determinadas mobilidades que, na verdade, se tecem com múltiplos deslocamentos regionais, transfronteiriços, interurbanos, transnacionais e que implicam deslocamentos de categorias sociais (TOGNI, 2014).

Inclusive, mostramos como uma leitura como a analisada, próxima do que Nina Glick Schiller e Noel Salazar (2012) têm chamado "nacionalismo metodológico", não parece distanciar-se o suficiente das categorias sociais que organizam o problema analisado; isto é, nação/região/etnia e migração. Prestar excessiva atenção à nação - como entidade explicativa, como recorte analítico, como vetor de expulsão, de criação de problemas e de potencial resolução dos mesmos - e ao migrante - como estrangeiro, como vulnerável, como sem estado/terra/nação -, e partir do suposto da migração como um evento extraordinário, pode favorecer processos sociais e políticos de essencialização, de re- 
produção de desigualdades, de ansiedades reguladoras e de fechamento de (certas) fronteiras. Desse modo, parte da literatura analisada desdobra no plano acadêmico esse sistema presente no campo social.

Para sustentar essa afirmação, já na terceira sessão do artigo, propusemos uma abordagem alternativa que partiu do princípio de descentrar a nação como categoria analítica e da suspensão da ideia de migração como categoria englobante de deslocamentos, mobilidades e presenças. Nesse sentido, recorremos a propostas antropológicas e históricas que, considerando interseccionalidades na produção de diferenças e desigualdades (BRAH, 2006; PISCITELLI, 2008a), colocam no centro a fronteira como experiência social e processo empírico (GRIMSON, 2003; ZÁRATE, 2008; ALBUQUERQUE, 2010)e, que no lugar das migrações, estão mais preocupadas por pensar as "mobilidades" (SCHILLER \& SALAZAR, 2012; SCHILLER, 2010), o "movimento" (GUEDES, 2013) e as presenças e vidas urbanas transnacionais (SCHILLER, 2010) e transfronteiriças (STEHPEN, 2007; ALBUQUERQUE, 2010). Essa abordagem nos permitiu construir uma imagem densa e ampliada do território transfronteiriço e das suas mobilidades que, olhando desde o ponto de confluência tríplice, pode nos levar, minimamente, até cidades como Manaus, Iquitos (Peru) e Bogotá (Colômbia), em redes de relações e fluxos cotidianos e relativamente livres de pessoas e bens. Nesse sentido, como sugere Stephen (2007), a compreensão de mobilidades e deslocamentos peruanos em cidades como Manaus, implicam pensar o transfronteiriço como englobante do "nacional".

Por fim, consideramos que o caminho percorrido neste artigo, longe de ser um resultado consolidado de pesquisa, abre possibilidades para melhor formularmos problemas de investigação que digam respeito às maneiras diferenciadas e desiguais como em territórios de fronteira e transfronteiriços amazônicos os princípios de socialidade e de governamentalidade - incluída a nação - são construídos em âmbitos políticos e sociais cotidia- 
nos. Nesse sentido, o nosso artigo constitui um aporte desde a fronteira para os estudos sobre migrações, e desde as mobilidades para os estudos sobre fronteira.

\section{REFERÊNCIAS}

ALBUQUERQUE, José Lindomar. A dinâmica das fronteiras: os brasiguaios na fronteira entre o Brasil e o Paraguai. São Paulo: Annablume, 2010.

APONTE MOTTA, Jorge. Leticia y Tabatinga: transformación de un espacio urbano en la Amazonia. Tesis de Maestría en Estudios Amazónicos. Leticia: Universidad Nacional de Colombia, 2011.

BLANCHETTE, Thaddeus \& SILVA, Ana Paula. "On bullshit and the trafficking of women: moral entrepreneurs and the invention of trafficking of persons in Brazil." Dialectical Anthropology. June 2012, Volume 36, Issue 1-2, 2012.: pp 107-125.

BRAH, Avtar. "Diferença, diversidade, diferenciação". Cadernos PAGU (26), janeiro-junho de 2006: pp.329-376.

BRASIL. DECRETO № 6.975, DE 7 DE OUTUBRO DE 2009. Promulga o Acordo sobre Residência para Nacionais dos Estados Partes do Mercado Comum do Sul - Mercosul, Bolívia e Chile, assinado por ocasião da XXIII Reunião do Conselho do Mercado Comum, realizada em Brasília nos dias 5 e 6 de dezembro de 2002.

BRASIL. Secretaria Nacional de Justiça. Pesquisa sobre tráfico de pessoas nas áreas de fronteira. Brasília: Ministério da Justiça. 2013.

CAMPOS, Ana Maria. Dilemas da maternidade: assistência a grávidas na rede municipal de saúde de Benjamin Constant/AM. Trabalho de conclusão de curso em Antropologia Social, Universidade Federal do Amazonas, Instituto de Natureza e Cultura. Benjamin Constant: UFAM/INC, 2012.

CARDOSO DE OLIVEIRA, Roberto. 0 índio e o mundo dos brancos: a situação dos tukuna do Alto Solimões. São Paulo: Livraria Pioneira Editora, 1972.

"Los (des)caminos de la identidade", Apuntes de Investigación del CECYP, año $V, n^{\circ}$ 7, 2001, p. 9-29.

CHAUMEIL, Jean-Pierre. "Par delà trois frontières, l'espace central du Trapèze amazonien (Pérou, Colombie, Brésil)", Autrepart, n 14, 2000, p. 53-70. 
DIAS, Gustavo. "Tactics of Border Crossing Movement: Exploring the mobility of Brazilians through the Schengen and UK airspace". Dossiê Fronteiras. Revista Ambivalências. No prelo.

FELDMAN-BIANCO, Bela. "Reinventando a localidade: globalização heterogênea, escala da cidade e a incorporação desigual de migrantes transnacionais". Horizontes Antropológicos, Porto Alegre, ano 15, n. 31, jan./jun. 2009: 1950 .

OLIVEIRA, M.E.S. Fronteira Vivida: 0 imaginário sobre os imigrantes peruanos em Benjamin Constant-AM. Trabalho de Conclusão de Curso, Bacharelado em Antropologia. Instituto Natureza e Cultura. Universidade Federal do Amazonas. 2010.

GRIMSON, Alejandro. "Los procesos de fronterización: flujos, redes e historicidad". IN: Clara Inés García (ed). Fronteras: territorias y metáforas. Medellín: Hombre Nuevo Editores, 2003: 15-34.

GOULARD, Jean Pierre. "El Noroeste amazónico en perspectiva: una lectura desde los siglos V-VI hasta 1768." Mundo Amazónico, v(1), 2010: 183-213.

Ethniciser le territoire. Mouvements pendulaires transfrontaliers dans un contexte amazonien. Cahiers de Amériques Latines, 48-49, Institut des Hautes Etudes de l'Amérique Latine, 2005 p. 147-168.

GRUPO DAVIDA. "Prostitutas, 'traficadas' e pânicos morais: uma análise da produção de fatos em pesquisas sobre o 'tráfico de seres humanos"'. Cadernos PAGU (25), 2005: 153-185.

GUEDES, André. 0 trecho, as mães e os papéis: etnografia de movimentos e durações no norte de Goiás. Sao Paulo, Garamond, 2013.

HAESBAERT, Rogério. Multi/transterritorialidade e "contornamento": do trânsito por múltiplos territórios ao contorno dos limites fronteiriços. In: FRAGA, Nilson. Territórios e fronteiras: (re)arranjos e perspectivas. Florianópolis: Editora Insular, 2011: 15-32.

JAKOB, A.A. E. "A migração internacional na Amazônia Brasileira”. Informe Gepec, Toledo, v. 15, número especial, p. 422-442, 2011.

LÓPEZ GARCÉS, Claudia L. Pueblos indígenas, fronteras y estados nacionales: Reflexiones histórico-antropológicas desde las fronteras Brasil-Colombia-Perú y Bras il-Francia. Revista Mundo Amazónico 2, 2011 | 155-178.

Ticunas brasileros, colombianos y peruanos: etnicidad y nacionalidad en la región de fronteras del alto Amazonas/Solimões. Tesis de doctorado en antropología, Universidad de Brasília-UnB, 2000.

LOWENKRON, Laura. Gênero, Fronteiras e Estado: a construção do tráfico de 
pessoas em investigações e inquéritos policiais. Relatório de pesquisa de pós-doutorado apresentado à Fundação de Amparo à Pesquisa do Estado de São Paulo (FAPESP), 2014.

MACEDO, Guilherme Martins. Negociando a identidade com os brancos: política e religião em um núcleo urbano Ticuna. Rio de Janeiro: Museu Nacional-UFRJ, 1996. (Dissertação de Mestrado).

MOTTA Ochoa, Angélica. Sexualidade e gênero na Amazônia urbana do Peru. Tese de Doutorado em Saúde Coletiva; Universidade do Estado do Rio de Janeiro. Rio de Janeiro: UERJ, 2010.

OLIVAR, José Miguel. Mercados do sexo em territórios transfronteiriços: gênero e circulações na fronteira Brasil-Colômbia. Relatório final de pesquisa. Bolsa de Pós-Doutorado FAPESP, processo 2010/50077-1. Núcleo de Estudos de Gênero -PAGU / Unicamp. Campinas: PAGU/FAPESP, 2013.

. "O dia que o tráfico chegou na fronteira. Relatório de Tabatinga". In: Piscitelli, Adriana et ali. Relatório do Projeto Trânsitos, crime e fronteiras: gênero, tráfico de pessoas e mercados do sexo no Brasil, CNPq [processo 404868/2012-6], PAGU/Unicamp: Campinas, 2015.

OLIVEIRA, M. M. Mobilidade humana na tríplice fronteira Peru-Colombia-Peru e seus reflexos na cidade de Manaus. In: Seyerferth, G. (et. al). Mundos em movimentos: ensaios sobre migrações. Santa Maria: editora da UFSM, 2006.

Migrações fronteiriças: uma reflexão necessária no Amazonas. 2008.

. Refugiados colombianos na Amazônia: elementos para uma sociologia dos deslocamentos compulsórios. In: Silva, S, (org.). Migrantes em contextos urbanos: uma abordagem interdisciplinar. Manaus: Edua, 2010: 223-260.

OLIVEIRA FILHO, Joao Pacheco de. 1988. 0 nosso governo: os Ticuna e o regime tutelar. São Paulo: Marco Zero; Brasília: MCT/CNPq.

PANTEVIS, Yohana. Construyendo la historia ambiental de Leticia através de la pesca. Maestría en Estudios Amazónicos. Leticia: Universidad Nacional de Colombia, 2013.

PICÓN, Jorge E. "Leticia, la transformación urbana de una ciudad amazónica y fronteriza; 1867-1960." In: Zárate, C (org). Espacios urbanos y sociedades transfronterizas en la Amazonía. Leticia: Universidad Nacional de Colombia, sede amazonía, 2012: 98-123.

PINEDA, Roberto. "El río de la mar dulce. Imaginarios sobre la amazonia: los dilemas entre un paraíso y un infierno verde". In: J. Echeverri (Ed.) Amazonia colombiana: Imaginarios y realidades - gobernanza y sociedad. Bogotá: Universidad Nacional de Colombia (Cátedra Jorge Eliecer Gaitán), 2011. Pp. 77-91. 
PISCITELLI, Adriana et ali. Relatório do Projeto Trânsitos, crime e fronteiras: gênero, tráfico de pessoas e mercados do sexo no Brasil, CNPq [processo 404868/2012-6], PAGU/Unicamp: Campinas, 2015.

PISCITELLI, Adriana. Trânsitos: brasileiras nos mercados transnacionais do sexo. Rio de Janeiro: EDUERJ/ Clam, 2013.

"Procurando vítimas do tráfico de pessoas: brasileiras na indústria do sexo na Espanha". Revista interdisciplinar da mobilidade humana. V.19 noㅡ 37, 2011.

"Interseccionalidades, categorias de articulação e experiências de migrantes brasileiras". In: Sociedade e Cultura. v. 11, n. 2, jul/dez, 2008a pp. 263-274.

. “Entre as 'máfias' e a 'ajuda': a construção de conhecimento sobre tráfico de pessoas". Cadernos PAGU (31), julho-dezembro, 2008b.: 29-64.

REIS, Rodrigo Oliveira Braga Reis. Os Matsés e as fronteiras: conflitos, territorialização e a construção de uma identidade transfronteiriça. Programa de Pós-Graduação em Antropologia. Universidade Federal de Pernambuco, 2013.

RODRIGUES, Francilene; PEREIRA, Marina (org). Estudos transdisciplinares na Amazônia setentrional: fronteiras, migração e políticas públicas. Rio de Janeiro: Letra Capital, 2012.

SANTOS, A.R. A migração de peruanos para a Amazônia brasileira: uma discussão sobre redes migratórias, fronteiras e identidades 2012.Somanlu, an0 12, n. 02, jul-dez, 2012.

SCHILLER, Nina Glick. "Cities and Transnationality." In Gary Bridge and Sophie Watson (ed.) Blackwell's Companion to the City, Oxford: Blackwell, 2010.

SCHILLER, Nina Glick; SALAZAR, Noel. Regimes of Mobility Across the Globe. Journal of Ethnic and Migration Studies, Vol. 39, No. 2, 2012: 183-200.

SILVA, S. "Brazil, a new Eldorado for Immigrants? The Case of Haitians and the Brazilian Immigration Policy". Urbanities, Vol. 3 • No 2, 2013.

. "Hermanos amazônicos: processos identitários e estratégias de mobilidades entre peruanos e colombianos em Manaus". In: Silva, S, (org.). Migrantes em contextos urbanos: uma abordagem interdisciplinar. Manaus: Edua, 2010: 205-222.

SPRANDEL, Marcia Anita. "Vou pra rua e bebo a tempestade: observações sobre os dissabores do guarda-chuva do tráfico de pessoas no Brasil". Palestra oferecida no Seminário Internacional Re-Pensando Gênero e Feminismos, 20 anos do Núcleo de Estudos de Gênero PAGU. Campinas: PAGU/Unicamp, 2014. 
STEHPEN, Lynn. Transborder lives: indigenous Oaxacans in México, California and Oregon. Duke University Press: Durham and London, 2007.

TAUSSIG, Michael. Xamanismo, Colonialismo e o Homem Selvagem. São Paulo: Paz e Terra, 1993.

TEIXEIRA, Flávia. "L'Italia dei Divieti: entre o sonho de ser europeia e o babado da prostituição.” Cadernos PAGU (UNICAMP), v. 31, p. 275-308, 2008.

TOGNI, Paula. A Europa é o CACÉM. Mobilidades, gênero e sexualidade nos deslocamentos de jovens brasileiros para Portugal. Tese de doutorado. ICS; ISCTE, Programa de pós-graduação em antropologia social. Lisboa: ICS, ISCTE, 2014.

TORRES, I. e OLIVEIRA, M. M. Tráfico de mulheres na Amazônia. Florianópolis-SC: Editora Mulheres, 2012.

VICTORINO, Nicolás. “Conformación de un nodo de transfronterización en el bajo Caquetá-Japurá” In: Zárate, C (org). Espacios urbanos y sociedades transfronterizas en la Amazonía. Leticia: Universidad Nacional de Colombia, 2012: 262-282.

YAGÜE, Blanca. Haciendo comestible la ciudad. Los indígenas urbanos de Leticia y sus redes desde la Soberanía Alimentaria. Maestría en Estudios Amazónicos. Leticia: Universidad Nacional de Colombia, 2013.

ZÁRATE BOTÍA, Carlos. 2008. Silvícolas, siringueros y agentes estatales: el surgimiento de una sociedad transfronteriza en la amazonia de Brasil, Perú y Colombia -1880-1932. Leticia: Universidad Nacional de Colombia.

"Amazonia: la historia desde la frontera" In: J. Echeverri (Ed.) Amazonia colombiana: Imaginarios y realidades - gobernanza y sociedad. Bogotá: Universidad Nacional de Colombia (Cátedra Jorge Eliecer Gaitán), 2011. Pp. 55-76.

Recepção dos artigos: 30/06/2015

Data de aprovação 30/07/2015 